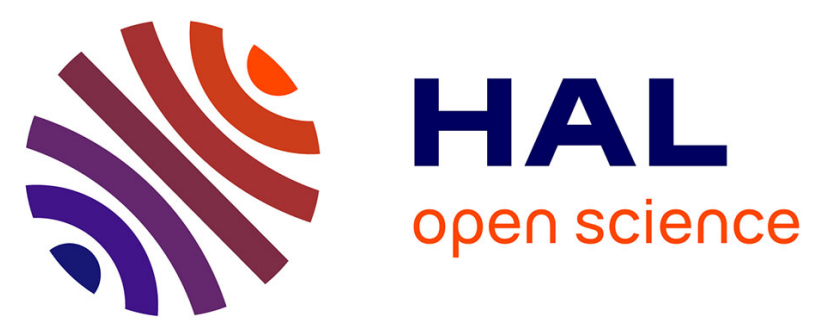

\title{
Seed losses at harvest and seed persistence of oilseed rape (Brassica napus) in different cultural conditions in Chinese farming systems
}

\author{
Y.M. Zhu, Y.D. Li, Nathalie Colbach, K.P. Ma, W. Wei, X.C. Mi
}

\section{- To cite this version:}

Y.M. Zhu, Y.D. Li, Nathalie Colbach, K.P. Ma, W. Wei, et al.. Seed losses at harvest and seed persistence of oilseed rape (Brassica napus) in different cultural conditions in Chinese farming systems. Weed Research, 2012, 52 (4), pp.317-326. 10.1111/j.1365-3180.2012.00929.x . hal-02647814

\section{HAL Id: hal-02647814 \\ https://hal.inrae.fr/hal-02647814}

Submitted on 29 May 2020

HAL is a multi-disciplinary open access archive for the deposit and dissemination of scientific research documents, whether they are published or not. The documents may come from teaching and research institutions in France or abroad, or from public or private research centers.
L'archive ouverte pluridisciplinaire HAL, est destinée au dépôt et à la diffusion de documents scientifiques de niveau recherche, publiés ou non, émanant des établissements d'enseignement et de recherche français ou étrangers, des laboratoires publics ou privés. 


\title{
Seed losses at harvest and seed persistence of oilseed rape (Brassica napus) in different cultural conditions in Chinese farming systems
}

\author{
Y M ZHU*, Y D LI $\dagger, \mathrm{N}$ COLBACH \\ * State Key Laboratory of Vegetation and Environmental Change, Institute of Botany, The Chinese Academy of Sciences, Xiangshan, Beijing, \\ China, $\dagger$ Institute of Agricultural Engineering, Jiangxi Academy of Agricultural Sciences, Nanchang City, Jiangxi Province, China, and $₫ I N R A$, \\ UMR1347 Agroécologie, ECOLDUR, Dijon, France
}

Received 15 October 2011

Revised version accepted 10 April 2012

Subject Editor: Peter Lutman, UK

\section{Summary}

This article reports experiments that explore the critical factors for gene flow in oilseed rape (Brassica napus) via the soil seedbank under Chinese farming systems. Research was carried out on 16 farmer's fields to estimate harvest seed losses after different planting methods and harvest timings, during the four components of the harvest operations. An additional field experiment was set up to estimate the potential germination proportion of seeds in flood-irrigated and unirrigated fields, as a function of seed burial depth over time. Seed losses were largest during the sun-drying of harvested plants in the field, accounting for about three quarters of the total seed losses. The number of intact seeds declined quickly after they entered the soil, particularly in un-irrigated fields, and no volunteers germinated in the irrigated field after 3 months. Burial depth did not affect the potential for germination and emergence of volunteers in the flood-irrigated field. However, the potential germination declined with increasing burial depth in the un-irrigated field. No viable seeds remained in the soil after 16 months. Seed losses during harvest could be limited to $0.7-1.1 \%$ by weight of total seed production by placing a plastic membrane under the cut plants during drying and no rape seeds could germinate after 3 months in waterlogged condition. Thus, the risk of gene flow via the soil seedbank is probably small in Chinese oilseed rape farming systems.

Keywords: volunteers, seed losses, intact seeds, potential germination proportion, seed dormancy.

Zhu YM, Li YD, Colbach N, Ma KP, Wei W \& Mi XC (2012). Seed losses at harvest and seed persistence of oilseed rape (Brassica napus) in different cultural conditions in Chinese farming systems. Weed Research 52, 317-326.

\section{Introduction}

In farmland, seed losses of oilseed rape (Brassica napus L.) during harvest are the main source of soil seedbanks. In Europe, harvest seed losses range from $2 \%$ to $5 \%$ of the yield even in optimal conditions (Price et al., 1996) and can reach up to $50 \%$ if harvesting is delayed, or after bad harvesting conditions (Macleod \& Green, 1981). These shed seeds can acquire secondary dormancy in the soil seedbank, if they experience unfavourable conditions for germination, such as water stress or/and oxygen deficiency (Pekrun et al., 1997a; Momoh et al., 2002). They can survive for up to 10 years (Schlink, 1998). Consequently, these seeds can give rise to volunteers in subsequent crops (Gruber \& Claupein, 2007). For instance, volunteer plants have been found 5-9 years after harvest of the last oilseed rape crop, both in Europe (Pessel et al., 2001) and in North America (Simard et al., 
2002). If these volunteers emerge in another cultivar of oilseed rape, they can reduce the quality of the harvest, for example, when high-erucic acid volunteers produce seeds in low-erucic acid cultivars.

Population dynamics models and simulations (Begg et al., 2006; Colbach et al., 2008; Middelhoff et al., 2011) have confirmed the key role of harvest seed losses and volunteers for spatio-temporal gene flow. This is particularly true in the case of co-existence of genetically-modified (GM) and non-GM oilseed rape. In China, the planting area of GM crops has expanded greatly, increasing to 3.9 million ha in 2011 (James, 2011). Because rape provides more than half of the edible oil and covers a third of the oil crop planting area $\left(7.3 \times 10^{6}\right.$ ha) in China (Zhou et al., 2011), GM rape may be introduced in the near future. It is therefore necessary to evaluate the potential risk of gene flow caused by GM rape in Chinese farming systems, and to suggest agronomic treatments to reduce potential risk.

There have been many studies on harvest losses of oilseed rape and their fate in the soil (Gulden et al., 2004; Gruber et al., 2005). However, these results are probably not transferable to the farming systems in China, with its very different pedo-climatic conditions, rotations and management techniques. The main oilseed rape production area in China is the Yangzi River Valley, where most rape crops are rotated with rice planted in flood-irrigated fields. These are waterlogged, which probably influences the behaviour of seeds in the soil (Pekrun et al., 1997a). In addition, two crops are usually grown per year, reducing the time that the land is allowed to rest before the next crop (Momoh \& Zhou, 2001; Zhou, 2001). Rape is either sown directly in fields in September or transplanted manually in October from nurseries. At harvest (in May), rape plants are cut manually when approximately two-thirds of the pods have turned yellow and left to dry in the field before being carried to a threshing machine. The subsequent crop is usually rice or cotton, planted during late May and harvested in September/October. If the subsequent crop is rice, the water-logged period is usually from late May to one or 2 weeks before rice harvest (late September to October). Flood irrigation and ploughing thus usually occur immediately after the harvest of rape. Furthermore, small farms and complicated topography make it difficult to mechanise production. All these manual operations are likely to affect harvest seed losses and the behaviour of seeds in the soil.

The objectives of this study were to identify the critical factors determining the probability of creating a rape soil seedbank and resulting volunteers, and thus to provide an indication of possible gene flow via the soil seedbank for the most common cropping system in the largest oilseed rape growing region in China. Research on farmer's fields was carried out to estimate harvest seed losses after different planting methods and harvest timings during the four harvest operations. An additional experiment was set up to assess potential seed survival and germination in flood-irrigated and unirrigated fields, as a function of seed burial depth over time. Ultimately, our work will provide basic parameters for modelling gene flow, to evaluate potential risks of GM gene movement in Chinese farming systems.

\section{Materials and methods}

\section{Measuring harvest seed losses of winter oilseed rape}

Trials on farmers' fields were conducted in Ningxiang County $\left(28^{\circ} 18^{\prime} \mathrm{N}, 112^{\circ} 29^{\prime} \mathrm{E}, 37 \mathrm{~m}\right.$ above sea level on average) located in the Yangtze River valley (hydromorphic paddy soil), in 2005 and 2006. The oilseed rape cultivar was Xiangyou 15. The preceding crop planted in all fields from May to October was rice.

Sixteen fields $\left(20 \times 20 \mathrm{~m}^{2}\right)$ were randomly selected in one farming region. In half of the fields, seeds were directly sown $\left(34 \pm 10\right.$ plants $\mathrm{m}^{-2}$, sown in the middle of October on the same date in both years); in the other half, seedlings were transplanted in late October on the same date in both years from nurseries where the seedlings had emerged in early September $\left(6 \pm 3\right.$ plants $\left.\mathrm{m}^{-2}\right)$. Half of each field was harvested at the traditional harvest date when two-thirds of the pods had turned yellow (11 May in both years); the other half was harvested 7 days later. Total crop yield was measured in four fields of each sowing system in five randomly placed $2 \times 2 \mathrm{~m}^{2}$ subplots per field; these subplots were carefully harvested by hand with a sickle $10 \mathrm{~cm}$ from the soil surface at the traditional harvest date, allowed to dry and then threshed by hand.

Seed losses were assessed on five $2 \times 2 \mathrm{~m}^{2}$ subplots randomly placed in each field, amounting to a total of 80 subplots, distinguishing seed shed (i) before cutting, (ii) during rape stem cutting (with a sickle), (iii) when the plants were left to dry where they had been cut for 4 days after cutting and (iv) when moving the plants to the wooden threshing bin. To measure seed losses before and during cutting, six rectangular trays $\left(20 \times 30 \mathrm{~cm}^{2}\right)$ containing cotton flannel (to prevent seeds from bouncing out) were put evenly in the subplots after flowering to collect the shed seeds. During drying, the cut stems were placed on a $2 \times 2 \mathrm{~m}^{2}$ plastic sheet in the same subplot and after 4 days drying, the shed seeds were collected from the sheet. To collect seeds lost during transportation to the threshing machine, another plastic sheet was put under the bundles of plants taken from the subplots.

The shed seeds collected from each harvest step, as well as the harvested yield, were separately put in a mesh bags $\left(20 \times 25 \mathrm{~cm}^{2}\right)$ and air-dried at $30^{\circ} \mathrm{C}$ for $48 \mathrm{~h}$ to a 
moisture content of approximately $8 \%$. Then, the collected seeds were separated from unwanted trash with a No.30 $(3 \mathrm{~mm})$ round sieve and weighed.

An additional investigation was conducted in 2007 to estimate the seed losses from immature green pods during threshing. Three $2 \times 2 \mathrm{~m}^{2}$ subplots were randomly selected in both direct-sown and transplanted fields. After cutting and drying, the stems were taken to be threshed. The remaining pods on the stems after threshing were collected and their seeds extracted carefully and weighed.

\section{Seed burial experiment in an irrigated and an un-irrigated field}

The cultivar of the buried seeds was Xiangyou 15, which is one of the most frequently grown cultivars in China. To test the germination rate of the cultivar, 1000 seeds were placed into ten Petri dishes $(9 \mathrm{~cm}$ diameter with a cover, 100 seeds per dish) with two layers of filter paper and $8 \mathrm{~mL}$ of distilled water. Half of the dishes were placed in the dark and the rest were exposed to light at $20^{\circ} \mathrm{C}$ for 4 days.

\section{Seed burial}

In Ningxiang County $\left(28^{\circ} 18^{\prime} \mathrm{N}, 112^{\circ} 29^{\prime} \mathrm{E}, 37 \mathrm{~m}\right.$ above sea level on average, hydromorphic paddy soil), a $20 \times 20 \mathrm{~m}^{2}$ environmentally homogenous field, was split equally into two parts. One part was flood-irrigated after seed burial, with a permanent water height of $1-2 \mathrm{~cm}$, while the other remained un-irrigated. Rape seeds were harvested on 12 May 2004 and then stored at $25 \pm 5^{\circ} \mathrm{C}$ and a relative humidity of $60 \%$ before burial, to simulate conditions comparable to exposure on the soil surface. Nylon mesh bags $\left(10 \times 15 \mathrm{~cm}^{2}\right)$ with a mesh size of $0.5 \mathrm{~mm}$ were used to contain the seeds. Every bag was filled with 300 dry seeds. A total of 384 bags were buried in 96 locations in the two field halves, at a depth of 2.5 , $7.5,12.5$ and $17.5 \mathrm{~cm}$ in each burial position on 23 May 2004, with one bag per layer. Burial depths were chosen to encompass all depths up to the usual ploughing depth of $<20 \mathrm{~cm}$. The burial date simulated the date of tillage after the harvest of the rape.

Two locations of buried seeds were randomly excavated in each part of the field every month, from 23 June 2004 to 23 September 2005. Seeds were recovered manually from the seed bags, separating rotten seeds (i.e. soft under the pressure of tweezers) from intact seeds.

\section{Germination tests}

All intact seeds were tested for germination ability after exhumation. All the intact seeds from each bag were transferred to Petri dishes $(9 \mathrm{~cm}$ diameter), with a maximum of 30 seeds per dish. Each Petri dish (with a cover) contained two layers of filter paper and $8 \mathrm{~mL}$ of distilled water and was placed for 7 days at $20-30^{\circ} \mathrm{C}$ in a room under natural light. Any seed with a visible radicle was considered to be germinating. The number of germinated seeds was related to the initially number of buried seeds, and this was considered as the potential for germination of volunteers and called the potential germination proportion (PGP).

\section{Dormancy test of the variety Xiangyou 15}

The Rapid Dormancy Test (RDT) method described by Weber et al. (2010) was used to test the capacity of secondary dormancy of Xiangyou 15 in December 2010 to January 2011. The seeds were harvested in May 2010 and stored at $25 \pm 5^{\circ} \mathrm{C}$ and a relative humidity of $60 \%$. The test was set up in five dishes with 100 rape seeds each. Seeds were left for 7 days in darkness at $20^{\circ} \mathrm{C}$ with PEG6000 solution ( -15 bar) for dormancy induction, followed by 7 days in distilled water in darkness at $20^{\circ} \mathrm{C}$ for germination tests.

\section{Field survey of volunteers after rape crops}

A field survey was conducted to assess the number of oilseed rape volunteers emerging from five to 10 months after the harvest of a rape crop, either after irrigated rice or after un-irrigated cotton. Surveys were carried out in Lixian, Hunan Province $\left(29^{\circ} 53^{\prime} \mathrm{N}, 111^{\circ} 39^{\prime} \mathrm{E}\right)$ in fields that had grown oilseed rape in the previous winter to spring (harvested in May 2004 and 2005 respectively) and then followed by either cotton or rice in summer to autumn. Volunteers were counted in the following spring (30 March 2005 and 12 March 2006). No crop was grown after the harvest of the cotton or rice (October 2004 and 2005 respectively). Twenty cotton fields and 20 rice fields ranging from 12 to $280 \mathrm{~m}^{2}$, and 23 cotton fields and 23 rice fields ranging from 22 to $100 \mathrm{~m}^{2}$ were investigated in 2005 and 2006 respectively. All rape volunteers in each field were counted.

\section{Data analysis}

\section{Seed losses experiment}

Weights of shed seeds were calculated as percentages relative to the total seed yield in each subplot per year, and mean percentages of the five subplots of each field were calculated. The Multivariate procedure (MANOva) of SPSS 16.0 (SPSS, 2007) was used to analyse the effects of planting methods, harvest dates and growing year on seed losses in four harvest steps, that is, (i) before harvest, (ii) during stalk cutting, (iii) during drying and (iv) when moving the plants to the threshing location. The difference in seed losses between harvest steps was analysed with the Tukey's test provided in the one-way ANOVA procedure. A two-tailed $t$-test was used 
to compare the seed losses from immature green pods during threshing of direct-sown rape and transplanted rape in the 2007 investigation.

\section{Seed burial experiment}

An exponential equation was fitted to the proportion of intact seeds (i.e. the proportion of intact seeds relative to the initially buried seeds) with time for each land management and seed depth, using the Nonlinear procedure of SPSS 16.0:

$$
\mathrm{PI}=\exp (-A \times \text { time })
$$

PI was the proportion of intact seeds observed at a given burial depth for a given land management strategy. A was a shape parameter and time was the burial time in months. The effect of land management and burial depth on A was then tested with the ANOvA.

For each excavated bag of seeds, the proportion of germinating seeds relative to the initially buried seeds (PGP) was calculated. PGP data were transformed to a logistic form to meet the assumption of normality and adjust to stabilise the variance:

$$
y=\ln ((\mathrm{PGP}+0.0001) /(1-\mathrm{PGP}))
$$

where $y$ is the transformed value. The analysis of covariance was performed by Univariate procedure in SPSS 16.0 to analyse the effect of burial depth and irrigation system with burial time (16 months) as the covariate value.

An exponential equation was fitted to the PGP in the un-irrigated field with time for every burial depth using the nonlinear procedure of SPSS 16.0:

$$
\mathrm{PGP}=\exp (-A \times \text { time }) .
$$

Time was the burial time in months. Additionally, a correlation procedure was used to analyse how PGP was related to $\mathrm{PI}$.

\section{Volunteer survey}

The number of oilseed rape volunteers in each field was divided by the area, to calculate the density. The Univariate procedure was used to compare the number of oilseed rape volunteers per $\mathrm{m}^{2}$ recorded in different years and crops.

\section{Results}

\section{Harvest seed losses}

Total harvest seed losses ranged from $3.0 \%$ to $7.6 \%$ of the yield by weight in 2005 and 2006, corresponding to a range of 836 (transplanted oilseed rape harvested at traditional date) to 1043 (direct-sown oilseed rape, delayed harvest) seeds per $\mathrm{m}^{2}$. No seed losses were observed before cutting, even when harvest was delayed. Seed losses during drying were significantly higher than during cutting $(P<0.001)$ and during transportation to where the plants were to be threshed $(P<0.001)$. Seed losses during cutting and transportation were similar (Fig. 1).

Although there was considerably more precipitation in 2005 than in 2006 during harvest (Fig. 2), it did not significantly affect either the total seed losses or the seed losses during cutting and drying (Fig. 1A, Table 1). Seed losses during transportation were significantly less in 2005 than in 2006.

During all harvest processes, seed losses from transplanted oilseed rape were significantly less than from direct-sown fields (Fig. 1B). The harvest date also significantly affected the seed losses (Table 1) during cutting and transportation, as well as the total amount of seed losses, with significantly lower losses when harvesting on the traditional date (Fig. 1C). Total seed losses varied more between planting methods than harvesting dates.

The investigation of seeds in immature pods showed that it accounted for $1.8 \pm 0.6 \%$ (transplanting) and $3.5 \pm 0.3 \%$ (direct seeding) of the total seed production, if the fields were harvested at the traditional date. This survey also showed a pattern similar to that of the previous experiment when comparing the seed losses of transplanted and direct seeded oilseed rape.

\section{Dormancy potential of the tested cultivar}

The germination test showed that more than $95 \%$ of the unburied seeds germinated in 3 days, both in dark and in light. The Weber test showed that $1.2 \pm 0.64 \%$ of seeds became dormant.

\section{Persistence of intact seeds}

The exponential Eqn (1) could be satisfactorily fitted to the proportion of intact seeds at four depths in un-irrigated land. In the irrigated field, the accuracy of fit declined with burial depth (Table 2). The analysis of the shape parameter of Eqn (1) with ANOvA showed that land management significantly affected the proportion of intact seeds, with a faster decrease in the un-irrigated versus irrigated field (Tables 2 and 3). After 1 year of burial, the proportion of intact seeds was close to zero in both fields (Fig. 3). The effect of burial depth was not significant.

\section{Proportion of potential germinated seeds}

The proportion of germinating seeds was lower than the proportion of intact seeds. Burial time was the 

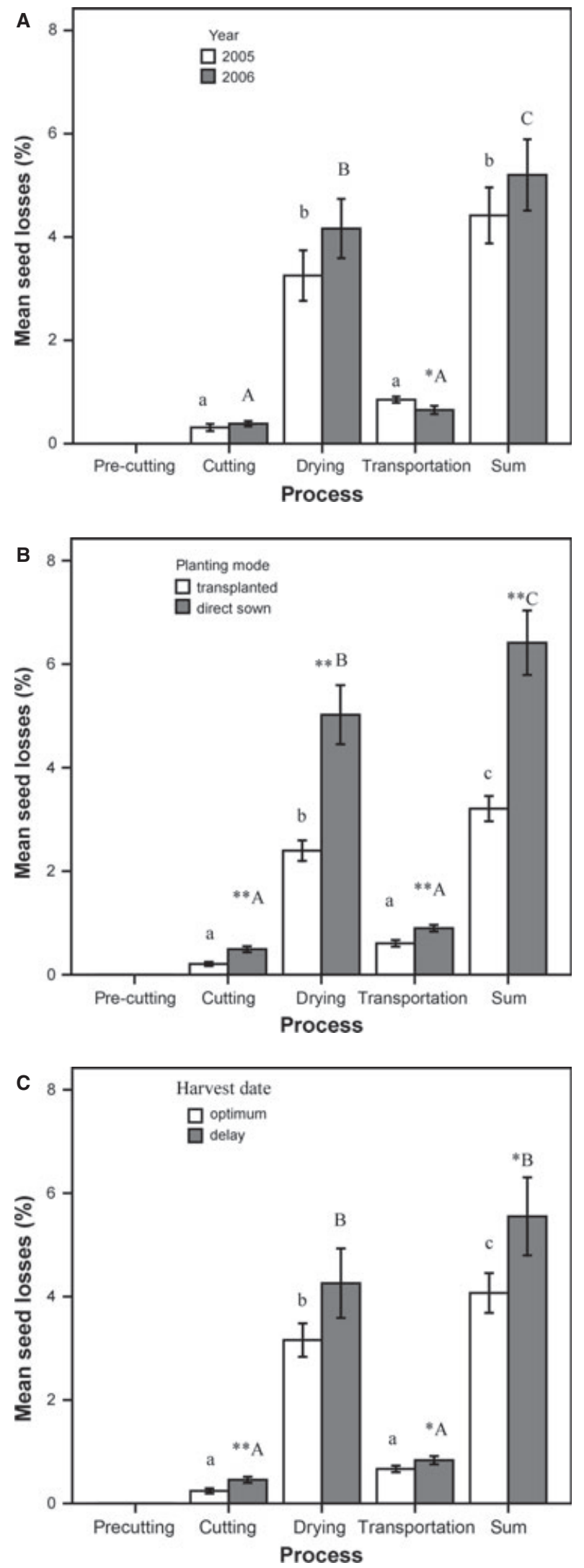

Fig. 1 Mean harvest seed losses relative to total seed production by weight during different harvest steps as a function of year (A), planting mode (B) and harvest date (C). Error bars show $\pm \mathrm{SE}$ of the mean.

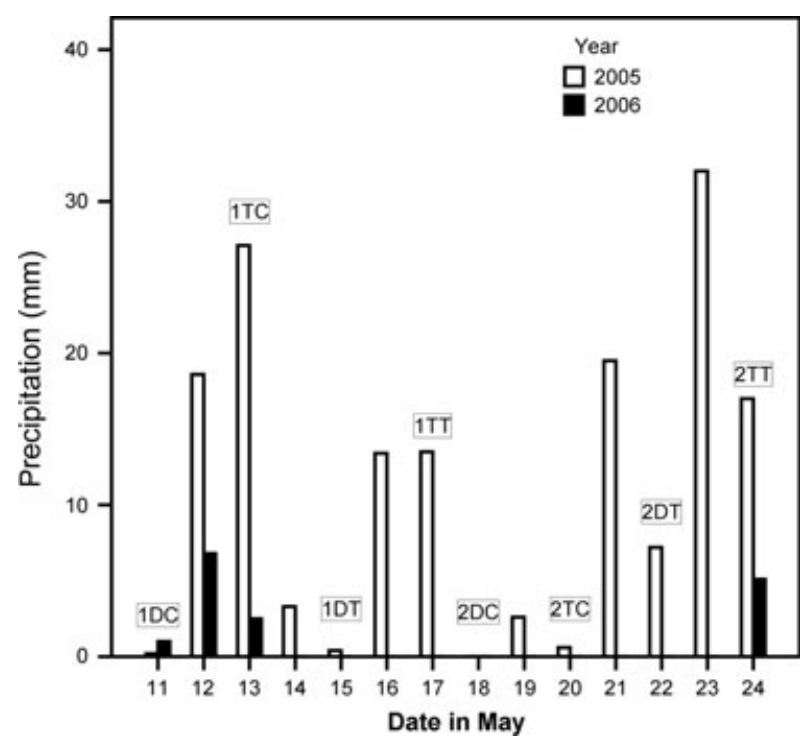

Fig. 2 Precipitation (mm per day) during harvest in 2005 and 2006. Letters on top of bars indicate the dates of harvest steps (1DC: traditional cutting date of the direct seeded oilseed rape; 1DT: transportation date of the direct seeded oilseed rape cut at traditional date; 2DC: late cutting date of the direct seeded oilseed rape; 2DT: transportation date of the direct seeded oilseed rape cut 7-day delay; 1TC: traditional cutting date of the transplanted oilseed rape; 1TT: transportation date of the transplanted oilseed rape cut at the traditional date; $2 \mathrm{TC}$ : late cutting date of the transplanted oilseed rape; 2TT: transportation date of the transplanted oilseed rape cut 7-day delay).

most important factor influencing the PGP, followed by irrigation system (Table 4). The effect of burial depth depended very much on the presence/absence of flood irrigation (Table 4). PGP was significantly higher in the un-irrigated versus irrigated fields (Table 5) and decreased significantly with burial depth in the unirrigated field, although not in the irrigated field (Table 6).

PGP decreased with increasing burial time, particularly during the first 3 months. In the irrigated field, no more germination occurred after this time. In unirrigated land, PGP could be fitted satisfactorily with an exponential Eqn (3) at each burial depth with time, with parameter $A=0.854,0.975,1.513$ and 1.735 for burial depths $2.5,7.5,12.5$ and $17.5 \mathrm{~cm}$, respectively, confirming that potential germination decreased fastest for the deepest seeds (Fig. 4). PGP was positively correlated with the PI $(P<0.001)$, and correlation was higher in the un-irrigated (correlation coefficient $=0.878$, ) than in the irrigated land $(0.728)$.

\section{Volunteer survey in crops after oilseed rape}

Irrigation system and growing year had a significant effect on volunteer density. No oilseed rape volunteers could be found in any of the flood-irrigated fields, 
Table 1 The significance of effects, presented as probability $(P)$ values, of the experiment year, planting mode and harvest date on the seed losses during different processes of harvest operation, with adjusted $R^{2}$ values

\begin{tabular}{lllll}
\hline Factor & Cutting & Drying & Transportation & Total \\
\hline Year & 0.144 & 0.108 & $0.009^{*}$ & 0.190 \\
Planting mode & $4.28 \times 10^{-6 *}$ & $6.67 \times 10^{-5 *}$ & $3.58 \times 10^{-4 *}$ & $1.15 \times 10^{-5 *}$ \\
Harvest date & $1.76 \times 10^{-4 *}$ & 0.055 & $0.025^{*}$ & $0.018^{*}$ \\
Year $\times$ planting mode & 0.196 & 0.154 & $0.014^{*}$ & 0.083 \\
Year $\times$ harvest date & $0.002^{*}$ & 0.578 & 0.165 & 0.685 \\
Planting mode $\times$ harvest date & 0.172 & 0.090 & 0.447 & 0.075 \\
Year $\times$ planting mode $\times$ harvest date & 0.157 & 0.545 & 0.102 & 0.516 \\
$R^{2}$ & 0.758 & 0.600 & 0.645 & 0.657 \\
\hline
\end{tabular}

The asterisks $\left(^{*}\right)$ mark the values of $P<0.05$. As no seed losses were found before cutting, data are not shown in the table.

Table 2 Effect of irrigation system and seed burial depth on proportion of intact seeds with time. Parameter estimation of equation $\mathrm{PI}=\exp (-A \times$ time $)$, with time being the burial time in months. Estimated parameter values and quality of fit

\begin{tabular}{lclll}
\hline $\begin{array}{l}\text { Irrigation } \\
\text { systems }\end{array}$ & $\begin{array}{l}\text { Burial } \\
\text { depth } \\
\text { (cm) }\end{array}$ & $\begin{array}{l}\text { Parameter } \\
\text { A }\end{array}$ & SE & $R^{2}$ \\
\hline Irrigated & 2.5 & 0.536 & 0.038 & 0.938 \\
land & 7.5 & 0.578 & 0.043 & 0.929 \\
& 12.5 & 0.539 & 0.051 & 0.877 \\
& 17.5 & 0.556 & 0.069 & 0.709 \\
Un-irrigated & All & 0.552 & 0.058 & 0.927 \\
land & 2.5 & 0.775 & 0.056 & 0.954 \\
& 7.5 & 0.798 & 0.052 & 0.964 \\
& 12.5 & 0.737 & 0.043 & 0.968 \\
& 17.5 & 0.783 & 0.038 & 0.967 \\
& All & 0.773 & 0.059 & 0.974 \\
\hline
\end{tabular}

Table 3 Effect of irrigation system and seed burial depth on proportion of intact seeds with time. Parameter estimation of equation PI $=\exp (-A \times$ time $)$, with time being the burial time in months. Effect of irrigation system and burial depth on parameter A

\begin{tabular}{lllll}
\hline Source & df & $\begin{array}{l}\text { Mean } \\
\text { Square }\end{array}$ & $F$ & $P$ \\
\hline $\begin{array}{c}\text { Irrigation } \\
\text { system }\end{array}$ & 1 & 0.098 & 658.53 & $1.30 \times 10^{-4}$ \\
$\begin{array}{c}\text { Burial } \\
\text { depth } \\
\begin{array}{c}\text { Corrected } \\
\text { Total }\end{array}\end{array}$ & 7 & 0.001 & 6.06 & 0.087 \\
\hline
\end{tabular}

whereas densities ranged from 0.11 to 6.18 plants $\mathrm{m}^{-2}$ in the un-irrigated fields. This is consistent with the lower germinability potential observed for the seeds in irrigated conditions in the burial experiment described earlier.

In the un-irrigated fields, significantly more oilseed rape volunteers were found in $2006(2.59 \pm 0.47$

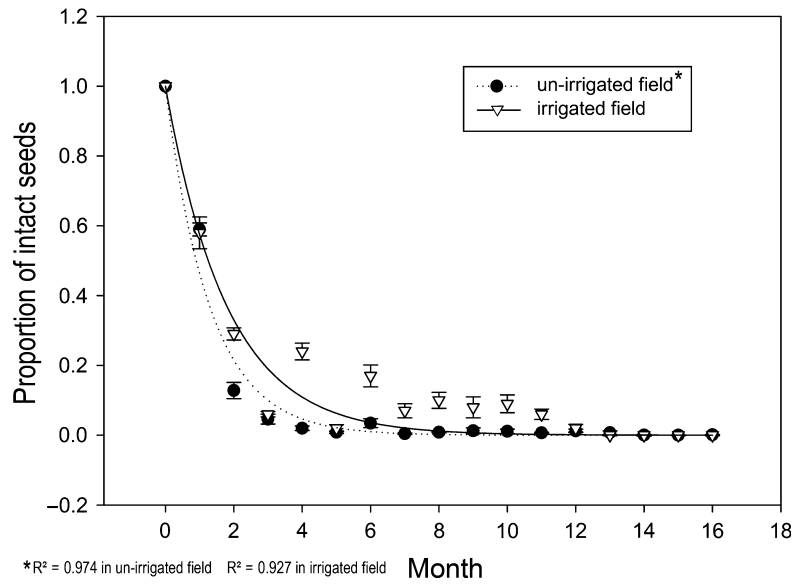

Fig. 3 Depletion of rape seeds in the soil. Proportion of intact seeds averaged over four soil layers and two sampling locations, over time and as a function of land management (no irrigation versus irrigation). Error bars show $\pm \mathrm{SE}$ of the mean.

Table 4 Effects of irrigation system and burial depth on PGP (transformed value) with burial time as co-variable. Results of analysis of covariance

\begin{tabular}{lrlll}
\hline $\begin{array}{l}\text { Explanative } \\
\text { factor }\end{array}$ & df & Mean Square & Partial R & $P$ \\
\hline $\begin{array}{c}\text { Time since } \\
\text { burial }\end{array}$ & 1 & 417.355 & 0.260 & $5.62 \times 10^{-21}$ \\
$\begin{array}{c}\text { Burial } \\
\text { depth }\end{array}$ & 3 & 11.713 & 0.022 & 0.032 \\
$\begin{array}{l}\text { Irrigation } \\
\text { system }\end{array}$ & 1 & 145.626 & 0.091 & $4.25 \times 10^{-9}$ \\
$\begin{array}{c}\text { Burial depth } \\
\times \text { irrigation } \\
\text { system }\end{array}$ & 3 & 15.302 & 0.029 & 0.010 \\
Error & 248 & 3.926 & & \\
\hline
\end{tabular}

plants $\left.\mathrm{m}^{-2}\right)$ than in $2005\left(0.75 \pm 0.19\right.$ plants $\mathrm{m}^{-2}$, $\mathrm{DF}=1, P=0.001)$. These densities are consistent with the seed losses (i.e. approximately 1000 seeds $\mathrm{m}^{-2}$ ) and PGP (i.e. range from $0 \%$ to $7.3 \%$ after 5 months) 
Table 5 Effects of irrigation system and burial depth on PGP (transformed value) with burial time as co-variable. Comparison of effects of irrigation (means of PGP of four burial depths and 16 months)

\begin{tabular}{llll}
\hline $\begin{array}{l}\text { Irrigation } \\
\text { system }\end{array}$ & $\begin{array}{l}\text { Means } \\
\text { (logit) }\end{array}$ & SE & $\begin{array}{l}\text { Means } \\
\text { (back } \\
\text { transformed) }\end{array}$ \\
\hline Irrigated & -8.618 & 0.156 & 0.006 \\
Un-irrigated & -7.173 & 0.259 & 0.033 \\
\hline
\end{tabular}

Table 6 Effects of irrigation system and burial depth on PGP (transformed value) with burial time as co-variable. Comparison of effects of burial depth and irrigation (means of PGP of 16 months per burial depth)

\begin{tabular}{|c|c|c|c|c|}
\hline & \multirow{2}{*}{$\begin{array}{l}\text { Burial } \\
\text { depth } \\
\text { (cm) }\end{array}$} & \multicolumn{3}{|l|}{ Means } \\
\hline & & $\begin{array}{l}\text { Transformed } \\
\text { value }\end{array}$ & SE & $\begin{array}{l}\text { Back-transformed } \\
\text { value }\end{array}$ \\
\hline \multirow[t]{4}{*}{ Irrigated } & 2.5 & -8.797 & 0.288 & 0.005 \\
\hline & 7.5 & -8.615 & 0.292 & 0.003 \\
\hline & 12.5 & -8.431 & 0.345 & 0.008 \\
\hline & 17.5 & -8.633 & 0.329 & 0.008 \\
\hline \multirow[t]{4}{*}{ Un-Irrigated } & 2.5 & -6.316 & 0.547 & 0.050 \\
\hline & 7.5 & -6.537 & 0.552 & 0.045 \\
\hline & 12.5 & -7.607 & 0.488 & 0.022 \\
\hline & 17.5 & -8.228 & 0.422 & 0.015 \\
\hline
\end{tabular}

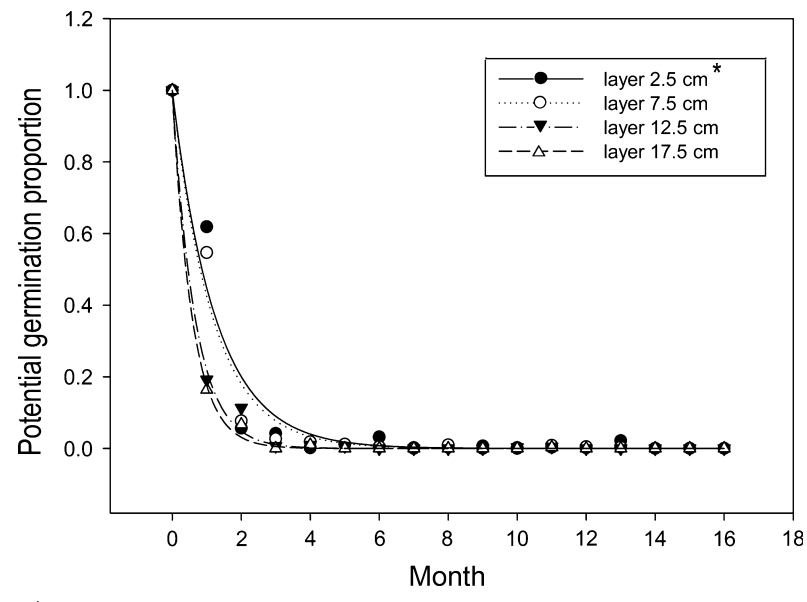

${ }^{*} R^{2}=0.954$ in layer $2.5 \mathrm{~cm} ; R^{2}=0.975$ in layer $7.5 \mathrm{~cm} ; R^{2}=0.995$ in layer $12.5 \mathrm{~cm} ; R^{2}=0.998$ inl layer $17.5 \mathrm{~cm}$

Fig. 4 Potential germination proportion of seeds in four soil layers (mean over two burial locations per exhumation date) in the unirrigated field. The lines show the fitting of Eqn (2) to the PGPs at four burial depths.

observed in the previous experiments, considering that not all germinated seeds give rise to viable adult volunteers.

\section{Discussion}

The seed losses during harvest observed in this study are relatively low compared with earlier reports from the literature (Price et al., 1996; Gulden \& Shirtliffe, 2003; Gruber et al., 2004). However, if the remaining seeds in immature pods were taken into account, the total seed losses would be $4.8-8.6 \%$ by weight (for harvest at the traditional date). As in most cases, the threshed stems are burnt, these additional seeds should not contribute to the soil seedbank.

In the present study, precipitation during harvest had little effect on total seed losses. In contrast to previous reports (Price et al., 1996; Pahkala \& Sankari, 2001), no seed losses were observed before harvest, even when the harvest was delayed. This could due to the relatively early harvest date in Chinese farming systems. Indeed, oilseed rape is usually cut when two-thirds of the pods become yellow and not when pods are totally ripe and thus fragile, as in more mechanised agriculture. Harvest date relative to maturity may also explain why seed losses are less in transplanted versus direct-sown oilseed rape. Indeed, pod maturity was more uniform when the oilseed rape seedlings were transplanted, with almost no overmature pods. The survey of the seeds remaining in the green pods partially supports this explanation, as fewer immature seeds were found in transplanted oilseed rape.

Seed losses during sun-drying were found to be the largest part of the seed losses, and these could be reduced in small-holder farms by spreading a plastic membrane under the cut plants during drying. The unwanted seedbank input because of harvest losses could thus be decreased to $1.1 \%$ in direct seeded and $0.7 \%$ in transplanted oilseed rape, if harvested at the traditional date.

Total seed losses were approximately seven times the actual sowing rate in our investigation. It appeared that seed losses during harvest (as opposed to sowing) were the main source of the soil seedbank in China, as in Europe and North America, even though the harvest procedures differ. These shed seeds would be buried at different depths in the soil by tillage (Roger-Estrade et al., 2001), which would affect seedling emergence and thus the volunteer populations (Messéan et al., 2007; Colbach et al., 2008).

Seed depletion in the soil in our experiment was believed to be due to germination, micro-predation, anoxia and disease, as retaining seeds in a bag made it impossible for any macro-predation or loss by animal transport to occur. After 4 months of burial, seed survival (i.e. $<2 \%$ and $24.5 \%$ in the un-irrigated and irrigated fields) seemed to be much lower in our study than that reported from Europe (Schlink, 1994). The proportion of intact seeds observed after 10 months (i.e. 
$0.6 \%$ and $2.5 \%$ seeds respectively) was also lower than survival values reported from Europe (Lutman et al., 2003). This difference could be due to differences in dormancy capacity between our seeds and those used by other authors. Indeed, secondary dormancy varies between genotypes (Momoh et al., 2002; Gruber et al., 2004; Gulden et al., 2004; Walker et al., 2004), influencing seed depletion through germination and thus seedbank persistence. Seed depletion might have been increased by rainfall just after harvest in May in the unirrigated land, triggering germination in the low-dormancy seeds (López-Granados \& Lutman, 1998). Moreover, the relatively high soil water content and lack of aeration predispose the seeds to pathogen infection and disease development (Rothrock, 1992). The last factor could have been influenced by the experimental method used. In the present study, seeds were buried without soil, thus increasing seed-seed contact and possible disease transmission (Van Mourik et al., 2005). However, another study also using soil-less bags and a lowdormancy variety observed a higher survival rate (i.e. $8 \%$ ) after a considerably longer burial length (Gruber et al., 2010). Our low survival rates are therefore probably due to environmental conditions, rather than to methodological differences.

Our study showed that more seeds stay intact in waterlogged conditions. This is consistent with previous studies showing that anoxia inhibits fungus growth (Griffin, 1972), thus reducing fungus-related seed decay. Another possible explanation is the absence of predators and aerobic pathogens in the anoxic condition in the irrigated field. The proportion of intact seeds in the irrigated field was highly variable, which may be correlated to the unevenly distribution of soil moisture. Yet Bekker et al. (1998) found that if the water content is too high (i.e. in water-logged conditions), high seed mortality usually is not caused by fungus decay, but by the effect of anoxia on seed metabolic processes. Moreover, previous reports showed that almost all seeds die after 4 weeks of imbibition under oxygen deficiency and adequate water supply (Pekrun et al., 1997a).

Potential germination proportion in our experiment represents the potential for emergence of volunteers over time, in irrigated and un-irrigated fields as a function of soil depth. Most of the decrease in germination potential in the present study was because of the decrease in intact seeds over time. The non-germinating intact seeds were probably dormant. Indeed, the proportion of intact seeds was shown above to be much lower than in other studies. Moreover, the variations in germination ability observed here were mostly consistent with variations in dormancy ability.

Indeed, in un-irrigated fields, PGP decreased with increasing burial depth. This is consistent with previous studies that showed that buried seeds became increasingly dormant with increasing seed depth (Gruber et al., 2010). Seed mortality can be excluded as a cause, as both the present and previous studies showed that the survival rate was not affected by the burial depth (Schlink, 1994; Gruber et al., 2010). No obvious difference between soil depths in germination potential was observed in the irrigated field, possibly because soil temperature varies less under water, even in the top layer in the soil, thus restricting germination (Pekrun et al., 1997b).

One of the limitations of the study is that we only tested one cultivar. Moreover, the dormancy potential of the cultivar used in the present study might have been overestimated, as the tested seeds had been stored for half year before the Weber test (Momoh et al., 2002) and did not originate from the same sample as the seeds used in the burial experiment. In addition, other Chinese cultivars exhibit a higher dormancy potential (Momoh et al., 2002) and could thus result in a higher risk of volunteers appearing after oilseed rape. However, the present study showed that the potential germination decreased quickly in irrigated fields, pointing to an overall low risk of volunteers in the flood-irrigated systems frequent in China. In un-irrigated fields, the potential of volunteers might be higher with different cultivars.

The oilseed rape volunteer densities observed in the field surveys were consistent with the seed loss, survival and germinability values measured in the various experiments, confirming that the risk of volunteers is higher in un-irrigated conditions. If these volunteers occurred in different rape varieties, their density (approximately 2$3 \%$ of crop density) was high enough to possibly cause harvest quality problems, such as exceeding the $0.9 \%$ GM seed threshold for non-GM food production chains in the European Union (European Commission, 2003) or the $3 \%$ alpha-linolenic acid threshold for oil production destined for frying (Carré et al., 2007).

\section{Conclusions}

This study is the first attempt to quantify source, risk and occurrence of volunteers resulting from oilseed rape cultivation in Chinese cropping systems, which differ considerably from the more frequently studied European systems. As rape crops usually rotate with flood-irrigated rice, the risk of gene flow via the soil seedbank should be limited, because the water-logged period severely reduces germination potential. Because of the lower harvest seed losses in fields due to manual harvesting and the larger proportion of seeds depleted in the soil, the probability of oilseed rape volunteers appearing in Chinese farmland does not seem as high 
as in Europe and America. In un-irrigated fields, volunteer occurrence was shown to be much more likely, because of better germination potential, particularly for shallowly buried seeds. In this situation, additional measures are necessary to reduce volunteer densities, for example, deep ploughing to reduce volunteer recruitment in crops following oilseed rape, particularly after cultivars with low-dormancy capability.

\section{Acknowledgements}

This work was supported by an Innovation Project of the Chinese Academy of Sciences (KSCX2-SW-124), a grant of National Natural Science Foundation of China (grant no. 30300044) and a joint PRA project between China and France named 'Managing gene flow from OSR and its effect on biodiversity in China farming system (E05-04)'. We are grateful to Henri Darmency, a Subject Editor and two anonymous reviewers for their insightful comments and suggestions.

\section{References}

Begg GS, Hockaday S, McNicol JW, Askew M \& Squire GR (2006) Modelling the persistence of volunteer oilseed rape (Brassica napus). Ecological Modelling 198, 195207.

BeKker RM, OOMEs MJM \& BAKKer JP (1998) The impact of groundwater level on soil seed bank survival. Seed Science Research 8, 399-404.

Carré P, Dartenuc C, Evrard J, Udde A, Labalette F \& Raoux R et al. (2007) Technological performances of low linolenic/high oleic rapeseed oils for food and non-food application. In: 12th International Rapeseed Congress, Vol. 5, 152-159, Wuhan, China.

Colbach N, Durr C, Gruber S \& Pekrun C (2008) Modelling the seed bank evolution and emergence of oilseed rape volunteers for managing co-existence of GM and non-GM varieties. European Journal of Agronomy 28, 19-32.

European Commission (2003) Regulation (EC) No 1829/2003 of the European Parliament and of the Council of 22 September 2003 on genetically modified food and feed, 1-23, Official Journal of the European Union.

GrifFIn DM ed. (1972) Ecology of Soil Fungi. Chapman \& Hall, London, UK.

Gruber S \& Claupein W (2007) Fecundity of volunteer oilseed rape and estimation of potential gene dispersal by a practicerelated model. Agriculture Ecosystems \& Environment 119, 401-408.

Gruber S, Pekrun C \& Claupein W (2004) Seed persistence of oilseed rape (Brassica napus): variation in transgenic and conventionally bred cultivars. Journal of Agricultural Science 142, 29-40.

Gruber S, Pekrun C \& Claupein W (2005) Life cycle and potential gene flow of volunteer oilseed rape in different tillage systems. Weed Research 45, 83-93.

Gruber S, Buhler A, Mohring J \& Claupein W (2010) Sleepers in the soil-vertical distribution by tillage and long- term survival of oilseed rape seeds compared with plastic pellets. European Journal of Agronomy 33, 81-88.

Gulden RH \& Shirtliffe SJ (2003) Harvest losses of canola (Brassica napus) cause large seedbank inputs. Weed Science 51, 83-86.

Gulden RH, Thomas AG \& Shirtliffe SJ (2004) Relative contribution of genotype, seed size and environment to secondary seed dormancy potential in Canadian spring oilseed rape (Brassica napus). Weed Research 44, 97-106.

JAmes C (2011) Global Status of Commercialized Biotech/GM Crops: 2011. Brief 43-2011: Executive Summary. ISAAA, Ithaca, NY, USA.

López-Granados F \& Lutman PJW (1998) Effect of environmental conditions on the dormancy and germination of volunteer oilseed rape seed (Brassica napus). Weed Science 46, 419-423.

Lutman PJW, Freeman SE \& Pekrun C (2003) The long-term persistence of seeds of oilseed rape (Brassica napus) in arable fields. Journal of Agricultural Science 141, 231-240.

Macleod J \& Green C eds. (1981) Oilseed Rape Book. A Manual for Growers, Farmers and Advisors. Cambridge Agricultural Publishing, Cambridge.

Messéan A, Sausse C, Gasquez J \& Darmency H (2007) Occurrence of genetically modified oilseed rape seeds in the harvest of subsequent conventional oilseed rape over time. European Journal of Agronomy 27, 115-122.

Middelhoff U, Reuter H \& Breckling B (2011) GeneTraMP, a spatio-temporal model of the dispersal and persistence of transgenes in feral, volunteer and crop plants of oilseed rape and related species. Ecological Indicators 11, 974-988.

Момон EJJ \& Zноu W (2001) Growth and yield responses to plant density and stage of transplanting in winter oilseed rape (Brassica napus L). Journal of Agronomy and Crop Science 186, 253-259.

Момон ЕJJ, Zноu WJ \& Ristiansson B (2002) Variation in the development of secondary dormancy in oilseed rape genotypes under conditions of stress. Weed Research 42, 446-455.

PAhKala K \& SANKari H (2001) Seed loss as a result of pod shatter in spring rape and spring turnip rape in Finland. Agricultural and Food Science in Finland 10, 209-216.

Pekrun C, Lutman PJW \& Baeumer K (1997a) Induction of secondary dormancy in rape seeds (Brassica napus L) by prolonged imbibition under conditions of water stress or oxygen deficiency in darkness. European Journal of Agronomy 6, 245-255.

Pekrun C, Lutman PJW \& Baeumer K (1997b) Germination behaviour of dormant oilseed rape seeds in relation to temperature. Weed Research 37, 419-431.

Pessel FD, Lecomte J, Emeriau V, Krouti M, Messean A \& Gouyon PH (2001) Persistence of oilseed rape (Brassica napus L.) outside of cultivated fields. Theoretical and Applied Genetics 102, 841-846.

Price JS, Hobson RN, Neale MA \& Bruce DM (1996) Seed losses in commercial harvesting of oilseed rape. Journal of Agricultural Engineering Research 65, 183-191.

Roger-Estrade J, Colbach N, Leterme P, Richard G \& CAneill J (2001) Modelling vertical and lateral weed seed movements during mouldboard ploughing with a skimcoulter. Soil \& Tillage Research 63, 35-49. 
Rothrock CS (1992) Tillage systems and plant-disease. Soil Science 154, 308-315.

Schlink S. (1994) Ökologie der Keimung und Dormanz von Körnerraps (Brassica napus L.) und ihre Bedeutung für eine Überdauerung der Samen im Boden. Dissertationes Botanicae, Band 222, Georg-August-Universität Göttingen, 193.

SCHLINK S (1998) 10 years survival of rape seed (Brassica napus L.) in soil. Zeitschrift Pflanzenkrankheiten Pflanzenschutz Sonderheft XVI, 169-172.

Simard MJ, Légère A, Pageau D, Lajeunesse J \& WARWICK S (2002) The frequency and persistence of volunteer canola (Brassica napus) in Quebec cropping systems. Weed Technology 16, 433-439.

SPSS (2007) SPSS 16.0 Base User's Guide, 1st edn. Prentice Hall Press, Upper Saddle River, NJ, USA.

VAn Mourik TA, Stomph TJ \& Murdoch AJ (2005) Why high seed densities within buried mesh bags may overesti- mate depletion rates of soil seed banks. Journal of Applied Ecology 42, 299-305.

Walker RL, Boоth EJ, Whytock GP \& Walker KC (2004) Volunteer potential of genetically modified oilseed rape with altered fatty acid content. Agriculture Ecosystems \& Environment 104, 653-661.

Weber EA, Frick K, Gruber S \& Claupein W (2010) Research and development towards a laboratory method for testing the genotypic predisposition of oilseed rape (Brassica napus L.) to secondary dormancy. Seed Science and Technology 38, 298-310.

Zноu WJ (2001) Oilseed rape. In: Crop Cultivation (eds GP Zhang \& WJ Zhou), 153-178. Zhejiang University Press, Hangzhou, China.

Zhou Z, Li J, Zhang Q \& Luo Q (2011) The developing status, problem and countermeasure investigation of the vegetable oil industry in China. Chinese Agricultural Science Bulletin 27, 92-97. 